\title{
Participation of Latvian Volunteers in Medical Aid to the Spanish Republic during the Spanish Civil War (1936-1939) ${ }^{1}$
}

\author{
Brīvprātīgo no Latvijas iesaiste medicīniskās palīdzības sniegšanā \\ Spānijas Republikai Spānijas pilsoṇu kara laikā (1936-1939)
}

\author{
Ginta leva Bikše, Mg. hist., PhD Cand. \\ Scientific Assistant at the Institute of Latvian History \\ University of Latvia, Kalpaka bulvāris 4, Rīga, LV-1050 \\ E-mail: ginta_ieva.bikse@lu.lv
}

Of more than 100 Latvian volunteers that participated in the Spanish Civil War, 15 were involved in providing medical aid to the Spanish Republic. Among these volunteers were both men and women, who worked not only as nurses but also as doctors. The aim of the article is to analyse the participation of Latvian volunteers in the Republican medical service (1936-1939) focusing on their motivation, arrival in Spain, activities during the conflict and departure from Spain. This article also includes information about Spanish Civil War participants of Latvian origin that had lost Latvian citizenship at the time of the conflict in order to provide a broader perspective to Latvian participation and its surrounding circumstances.

Keywords: Spanish Civil War, medical aid, medical personnel, Latvian volunteers, Latvian foreign policy.

No vairāk nekā 100 brīvprātīgajiem no Latvijas, kas piedalījās Spānijas pilsoṇu karā, 15 bija iesaistīti medicīniskās palīdzības sniegšanā republikāṇu kontrolētajās teritorijās Spānijā. Šo brīvprātīgo vidū bija gan vīrieši, gan sievietes, kuras strādāja ne tikai kā medmāsas, bet arī kā ārstes. Raksta mērkisis ir analizēt brīvprātīgo no Latvijas dalību Spānijas Republikas medicinas dienestā (1936-1939), pievēršot uzmanību viņu motivācijai, ierašanās laikam Spānijā, darbībām konflikta laikā un izcel̦ošanai no Spānijas. Rakstā iekḷauta informācija arī par Spānijas pilsoṇu kara dalībniekiem, kuri saistīti ar Latviju un kuri konflikta brīdī bija zaudējuši Latvijas pilsonību, tādējādi sniedzot plašāku ieskatu brīvprātīgo no Latvijas iesaistē karā.

Atslēgvārdi: Spānijas pilsoṇu karš, medicīniskā palīdzība, medicīniskais personāls, brīvprātīgie no Latvijas, Latvijas ārpolitika. 
When the Spanish Civil War broke out, Latvia was governed by Kārlis Ulmanis, who on 15 May 1934 organized a coup d'état and established an authoritarian dictatorship in Latvia. The regime was based on nationalism and was relatively mild in comparison with other dictatorships in Europe at the time. ${ }^{2}$ Furthermore, the regime did not support radicalism, although socialism, anarchism and communism were considered as particularly distant ideas. ${ }^{3}$ Latvia supported the NonIntervention Agreement, was a member in the Non-Intervention Committee, and on 23 February 1937 the Cabinet of Ministers prohibited Latvian citizens to participate in the Spanish Civil War. ${ }^{4}$ For some time, Latvian government was convinced that Latvia's involvement in the Non-Intervention Committee was symbolic, the Spanish Civil War - a distant development and that there were no signs of recruitment of volunteers in Latvia. ${ }^{5}$ Nonetheless, more than 100 Latvians participated in the conflict. The absolute majority of them supported the Republicans, however, one Baltic German volunteer had been in the Corps of Voluntary Troops (Italian: Corpo Truppe Volontarie, CTV) on Francisco Franco's side. ${ }^{6}$ Many Latvians that travelled to Spain were members of the illegal Communist Party or its satellite organizations. ${ }^{7}$ Some Latvians were participating in the Spanish Civil War not as volunteers but as Soviet military advisors, thus representing foreign policy of the Soviet Union. ${ }^{8}$

The Latvians in the Republican zone also included doctors, nurses and volunteers who assisted in providing medical care. The experience in war medicine gained during the Spanish Civil War and its achievements, especially in traumatology, were later used during the Second World War. ${ }^{9}$ As in any warfare, medical care was crucial in saving lives of wounded and sick soldiers, ensuring physical and mental health, rehabilitation, as well as in helping to return to front lines more quickly. Furthermore, foreign volunteers helped to promote hygiene among soldiers and to prevent diseases. By analysing Latvian involvement in medical services, the article will also assist in providing a more complete picture of foreign medical aid to the Spanish Republic.

Latvian involvement in the Spanish Civil War has not yet been thoroughly investigated. One of the most important publications on this matter Latvijas cinitāji Spānijā: 1936-1939: atminas un dokumen$\mathrm{ti}^{10}$ - a collection of memoirs and documents on Latvian fighters in Spain - was prepared in Latvian Soviet Socialist Republic (Latvian SSR) by the Institute of Party History of the Central Committee of the Latvian Communist Party and published in 1966. The publication had to highlight the role of the Communist Party and needed to have an "educational nature", therefore those Latvians, who did not meet the criteria either due to their character or the choice to remain abroad, where erased from Soviet history. ${ }^{11}$ An attempt to investigate the participation of Latvian volunteers in the conflict has been made by Ignacio de la Torre, ${ }^{12}$ however, the lack of Latvian language proficiency caused many sources in Latvian to be overlooked, and that has led to overestimation of Latvian involvement and factual errors. Some publications ${ }^{13}$ during different time periods have focused on specific Latvians that participated in the Spanish Civil War, nevertheless, the overall picture of Latvians in the Spanish Civil War remains unclear. As the very important aspect of medical aid during conflicts has often received less attention by historians, ${ }^{14}$ logically providing an overview of Latvian volunteers in medical aid to Spanish Republic has, likewise, been neglected. This article attempts to remedy this deficiency and to contribute 
to better understanding of Latvian involvement in the Spanish Civil War.

The aim of the article is to analyse the participation of Latvian volunteers in the Republican medical service (19361939), focusing on their motivation, arrival in Spain, activities during the conflict and departure from Spain. This article also includes information about volunteers of Latvian origin that had lost Latvian citizenship at the time of the conflict in order to provide a broader perspective to Latvian participation and its surrounding circumstances. The main sources consist of materials from the personal files in the funds of the Latvian Diplomatic and Consular Representations Abroad (No. 2575) and Administrative Department of the Ministry of the Interior (No. 3234) of the Latvian State Historical Archives, Latvian National Archive; notes, memoirs and biographical data from the funds of Institute of Social Policy Research of the Central Committee of the Latvian Communist Party - Branch of the Institute of Marxism-Leninism of the Central Committee of the CPSU (PA-200) the State Archives of Latvia, Latvian National Archive, as well as correspondence, orders, characterizations and other materials from the fund of the Interbrigades of the Spanish Republican Army (No. 545) at the Russian State Archive of Socio-Political History. Relevant literature and published memoirs ${ }^{15}$ have been used in order to explain and complete the data provided by archival materials.

\section{Motivation for participation and arrival in Spain}

Very shortly after the military uprising, foreign doctors, nurses and other volunteers left their previous lives, countries and often respectable jobs in order to provide medical care to wounded and sick soldiers.
One of the first Latvians to arrive in Spain was doctor Jēkabs Bahrahs (Bachrach, also known as Kuba) who reached Spain in 23 August 1936. ${ }^{16} \mathrm{~J}$. Bahrahs (Kuba), born in 1903 in a Jewish family in Poland, had received his degree in medicine, surgery and obstetrics from the Free University of Brussels and had mostly been living abroad (in France and Belgium) since 1926. Before leaving Latvia, J. Bahrahs (Kuba) completed his compulsory enrolment for service in Latvia's armed forces. After receiving the degree, J. Bahrahs (Kuba) tried to reestablish his life in Latvia but was faced with difficulties to enter the University of Latvia. ${ }^{17}$ At the time, the laws stipulated that it was necessary to have a diploma from the University of Latvia in order to practice medicine in the country. ${ }^{18}$ Unable to fully settle somewhere, J. Bahrahs decided to leave Brussels and to participate in medical aid to the Spanish Republic. ${ }^{19}$

Before the official decision of the NonIntervention Committee to impede foreign volunteers from participating in the Spanish Civil War and the following decision of the Latvian Cabinet of Ministers in 23 February 1937 to forbid Latvian participation in the conflict, several other Latvian volunteers - Voldemārs Kupcis, Semjons Levinsons, Civja Vospe, Lazars Kroms (also known as Len Crome), Žanis Artmanis (also known as Rūdolfs Tellers), Sāra Švalbe travelled to Spain to participate in medical aid. V. Kupcis, born in 1905 in a Latvian family, was the son of a professor at the University of Latvia - Jānis Kupcis. A former student at the Faculty of Chemistry at the University of Latvia and a member of a student corporation informed Latvian authorities that his reason for leaving Latvia was to travel to Belgium and France in order to learn more about synthetic minerals. ${ }^{20}$ To the Latvian legation in Paris V. Kupcis stated that he had decided to travel to Spain after an invitation by an 
English doctor and that he regretted this decision. ${ }^{21}$ S. Levinsons, a veterinarian born in 1906 in a Jewish family, had finished his studies in Brno, Czechoslovakia in 1936 and had been a member of Communist Party of Czechoslovakia when in December 1936 he decided to travel to Spain together with Czech communists. ${ }^{22}$ Also living abroad at the time and studying in Belgium was Civja Vospe, a Jewish woman and a communist born in 1906, who arrived in Spain sometime in $1936 .{ }^{23}$ To Latvian authorities in $1939 \mathrm{~J}$. Bahrahs (Kuba) stated that he was unmarried, but C. Vospe - divorced. ${ }^{24}$ However, in letters to J. Bahrahs (Kuba) written in 1939 she addressed herself as J. Bahrahs' (Kuba's) wife. ${ }^{25}$ Another foreign resident and even citizen was L. Kroms (Crome), born 1909 in Daugavpils in a Jewish family. L. Kroms (Crome) was not a communist at the time but the antisemitic character of the Nazi regime had directed him towards strong anti-fascist beliefs and motivated to travel to Spain at the beginning of 1937. L. Kroms (Crome) had received a degree in medicine in 1933 in Great Britain and became a British citizen in 1934, thus losing Latvian citizenship. ${ }^{26}$ Ž. Artmanis or, as known in Spain - R. Tellers - was a communist born in a Latvian family in 1897. He was one of several dozens of Latvians who went to Spain from the Soviet Union. Ž. Artmanis had specialized in protection against chemical warfare. ${ }^{27}$ As stated in Latvijas cinitāji Spānijā: 1936-1939: atminas un dokumenti, he was a volunteer, not a Soviet military advisor, and the author of this article currently has no sources that contradict this statement. ${ }^{28}$ Last but not least, S. Švalbe, born in 1904 in a Jewish family in Daugavpils, was a communist and had finished her studies in 1934 in Czechoslovakia and received qualification of a dentist in 1935. ${ }^{29}$ When the Spanish Civil War broke out, S. Švalbe was concerned about Italian and German intervention in Spain and decided to aid the Republicans in a meeting of communist students in Czechoslovakia. S. Švalbe left Prague on 26 January $1937 . .^{30}$

Several other Latvian volunteers were never sufficiently intimidated by the prohibition of European volunteers to participate in the conflict. In March 1937, two nurses from the Jewish hospital Bikur holim in Riga started their travel through Europe to Spain. Riva Volšonoka (later - Leiboviča, in Spain known as Era) was born in 1909 in a Jewish family. As a reason to receive valid documents for travel, R. Volšonoka stated the desire to attend the World Exhibition in Paris in 1937. Together with Frīda Gincburga (also known as Māra), likewise a Jewish woman, born in 1909, they arrived in Spain in April 1937 from France, where they had boarded a barge. ${ }^{31}$ Both nurses were members of the illegal Communist Party of Latvia. ${ }^{32}$ F. Gincburga's husband Aleksandrs Gincburgs was already in Spain since December $1936 .{ }^{33}$ Next to arrive in Spain was Ābrams Šalits, born in 1908 in a Jewish family. Ā. Šalits had finished his studies in medicine in 1935 in University of Siena in Italy and requested valid documents for travel in order to continue education in Italy. To Latvian authorities Ā. Šalits stated that after arriving in Sweden, from where he wished to travel further to Italy, he met representatives from international medical services that convinced him to travel to Spain. However, his mother testified that from the very beginning his intention was to go to Spain. ${ }^{34} \bar{A}$. Šalits entered Spain through France around 24-25 May 1937. ${ }^{35}$ In the same month, Peisahs Bernštams, a former doctor of Bikur holim hospital in Riga arrived in Barcelona onboard a ship from Marseille. P. Bernštams, born in 1907 in a Jewish family in Bauska, had finished his studies in Paris and was an active member of anti-fascist movement and a supporter 
of the Communist Party of Latvia. Before arriving in Spain, P. Bernštams had received a task from the communist organisations to travel to Sweden and arrange the passage for Latvian volunteers through Sweden to the Republican zone. As soon as this pathway was discovered by Swedish authorities, P. Bernštams left Sweden for Paris. ${ }^{36}$ In the autumn of 1937, three more Latvian volunteers arrived in Spain. Leiviks Gutkins, a doctor born in 1908 in a Jewish family, had finished his studies in Turin, Italy in 1935 and entered Spain in September, $1937 .{ }^{37}$ During the next month, Marina Strazde, born in 1897 in a Latvian family, entered Spain from Paris. M. Strazde had been living abroad for several years. ${ }^{38}$ The last two Latvian volunteers in medical aid to arrive in Spain were Jewish doctors and sisters Mirjama Rudina and Braina Rudina (known in Spain as Braina Voss). M. Rudina, born in 1898, had finished studies at the University of Siena in 1925, subsequently worked in Berlin and was involved in the International Red Aid (Mezhdunaródnaja organizácija pómoshhi borcám revoljúcii - MOPR), the same as her younger sister. B. Rudina, born in 1902, had finished her studies in Vienna in 1927. After gaining practical experience abroad both in medical work and communist activities, B. Rudina arrived in Spain only in January 1938, as on her way she had been arrested in Yugoslavia. Her husband was also in Spain. The Rudin family were represented in the Republican zone also by their brother Samuels Rudins, born in $1911 .^{39}$

\section{Work in Spain}

Some of the higher-level personnel during the Spanish Civil War were L. Kroms (Crome), B. Rudina (Voss), M. Rudina, V. Kupcis, J. Bahrahs (Kuba) and
Ž. Artmanis (R. Tellers). At first, L. Kroms (Crome) worked for the Scottish ambulance unit, but then joined the International Brigades, where he worked both as an assistant to the chief medical officer of the $35^{\text {th }}$ Division and a field surgeon but in 1937 he was promoted to the chief of the medical services to the $35^{\text {th }}$ Division. ${ }^{40}$ Due to denunciations in the International Brigades and paranoia of André Marty, the Political Commissar of the International Brigades, L. Kroms (Crome) was wrongly accused of spreading enemy propaganda and poor organisation of the medical services, nevertheless, he continued his work until the withdrawal of foreign volunteers. More about the experience of L. Kroms (Crome) in Spain can be found in Paul Preston's article. ${ }^{41}$ Another relatively well-known volunteer from Latvia was B. Rudina (Voss), who at first worked at Albacete but then in March 1938 was promoted to head of the hospital at Villanueva de la Jara. Around July 1938, after the evacuation of the hospital, she was appointed as the head of the S'Agaro hospital. ${ }^{42}$ In Spain, B. Rudina (Voss) was characterized as a qualified doctor, a very good organizer and politically reliable. ${ }^{43}$ She worked at the hospital until its evacuation in January $1939 .{ }^{44}$ S'Agaro was relatively close to the French frontier and the hospital was intended for those who were declared unfit for any further military service and awaited their repatriation. ${ }^{45}$ For a while, the head of a hospital was also B. Rudina's (Voss) sister M. Rudina who overviewed work at the Cueva de la Potita hospital that was specialized in psychiatry. ${ }^{46}$ After the evacuation of the hospital she worked also at the hospitals in Moya and S'Agaro. ${ }^{47}$ M. Rudina had left behind her two children to come to Spain, she was described as a qualified doctor, however, she was not very active politically and even her sister B. Rudina (Voss) described her as unsuited for work in difficult circumstances. ${ }^{48}$ 
V. Kupcis at first in Spain worked as a pharmacist at a hospital in Torrelodones, but later - as a pharmacist of the $35^{\text {th }}$ Division and the head of pharmaceutical services for the $\mathrm{V}$ and XV Corps. ${ }^{49}$ In Spain, V. Kupcis requested to be admitted in the Communist Party, although Latvian communist Rūdolfs Lācis (in Spain known as Vilks) described him as a son of the bourgeoisie and did not find any Marxist views in his mindset. Even if V. Kupcis was not a communist, other Latvians saw his abilities and had heard that he completed his tasks as a pharmacist in an exemplary manner. R. Lācis had doubts about V. Kupcis' resilience and ability to have the patience to complete long-term tasks. ${ }^{50} \mathrm{~J}$. Bahrahs worked in Albacete, around early 1938 he was the chief physician in Fortuna hospital, in October 1938 he started working in Mataro hospital. ${ }^{51}$ J. Bahrahs (Kuba) was associated with the "grouping" led by L. Kroms that was carrying out harmful activities and disobeying orders in the medical services. ${ }^{52}$ Probably, in Albacete J. Bahrahs (Kuba) crossed paths with Ž. Artmanis (R. Tellers) ${ }^{53}$ who was the head of anti-gas service in Albacete. ${ }^{54}$ Since April 1938 Ž. Artmanis worked in S'Agaro hospital with different assignments besides the immediate treatment of patients. ${ }^{55}$

Short memoirs on experience in Spain written by doctors S. Švalbe, P. Bernštams, L. Gutkins and S. Levinsons were published in Latvijas cinitāji Spānijā: 1936-1939: atminas un dokumenti. At first, for two months S. Švalbe worked in a hospital in Albacete, but after she was transferred to the $11^{\text {th }}$ International Brigade, where for a while she worked as a dentist in a dental ambulance, but later treated wounded soldiers. S. Švalbe wrote that working conditions were very hard during the battle of Brunete, and she worked day and night in hospitals near the front, where she treated the recently operated men. From
May 1938, S. Švalbe worked as a doctor in $\mathrm{XV}$ Corps and the $35^{\text {th }}$ Division but since October 1938 she was under B. Rudina's (Voss') supervision in S'Agaro hospital. ${ }^{56}$ P. Bernštams also had his first employment experience in Spain in Albacete. He was working with the newly recruited. Some of his main tasks were to inspect the barracks and eliminate unsanitary conditions. Besides providing medical services, P. Bernštams mentioned that there was a task to detect foreign intelligence agents. He wrote:

"[...] along with honest, selfless fighters, all sorts of adventure seekers, loafers and idlers, as well as provocateurs sent by intelligence bodies of the capitalist lands arrived in Albacete. They had to be exposed and got rid of soon." 57

In September 1937, after establishing strict order in Albacete, he finally received permission to go to the front. P. Bernštams was a doctor for the $15^{\text {th }}$ International Brigade until the withdrawal of foreign volunteers. His memoirs give the impression that he was very organized and capable of spotting issues that needed to be solved. P. Bernštams described his work both with civilians and soldiers, mentioning how in December 1937 there was an epidemic of flu and typhoid fever in the brigade, and how with directives he could enforce mandatory showers for soldiers, changing of clothes and disinfection. ${ }^{58}$ Latvian medical personnel were mostly treating the International Brigades, however, L. Gutkins was providing medical aid to Spanish units in Central Spain and was withdrawn from Central Spain only in February 1939. ${ }^{59}$ In memoirs focusing on leaving Spain, he has not shared much about his experience as a doctor during the conflict. Among Latvian medical professionals there was one veterinarian - S. Levinsons, who mostly worked 
in the $15^{\text {th }}$ International Brigade. To fulfil his duties, S. Levinsons had a chauffeur and a motorcycle with a sidecar. In one of his trips, S. Levinsons met with an accident and became a patient himself. ${ }^{60}$

$\bar{A}$. Šalits was also engaged in treating patients. He worked as a doctor in the $14^{\text {th }}$ International Brigade and from around January 1938 to April 1938 in hospital in Benicasim, and then until December 1938 - in hospital in Mataro, where he operated J. Bahrahs to treat a medical condition (hernia) obtained during work. ${ }^{61}$ In Spain, Ā. Šalits was described as a qualified doctor, albeit with unclear political convictions. Besides Latvian, German and Russian, he also spoke Polish, Czech, English, French, Italian and Spanish. ${ }^{62}$

Among Latvian nurses, R. Volšonoka (Era) seemed to be the most active in Spain. She worked both in rear (for example, Murcia, S'Agaro) and front hospitals (near Belchite, Cordoba etc.). In her memoirs, she wrote that from Albacete she was sent to Murcia, but her desire was to work in a hospital near front lines, and therefore she requested to be transferred. In Spain, R. Volšonoka (Era) also met other Latvians who fought in the International Brigades and in memoirs described their encounters. Furthermore, she briefly outlined the work of organising hospitals near frontline, their necessary disinfection, the work with large number of injured soldiers and the success of blood transfusions. Both her memoirs and articles about her during the Spanish Civil War showed that R. Volšonoka (Era) was very interested in supplying healthy food to patients. She was deeply upset when she could not obtain more healthy food to Latvian Jānis Palkavnieks from the $13^{\text {th }}$ International Brigade, also a communist, who was in a hospital with a digestive disease. ${ }^{63}$ She was also a contact person for Latvians living in the United States of America, which meant that she received packages, for example, newspapers that R. Volšonoka later sent to other Latvians fighting in the front on the Republican side. ${ }^{64} \mathrm{~B}$. Rudina (Voss) described her as very active and well qualified, although as a communist she was an intriguer. ${ }^{65}$

The work of other nurses - F. Gincburga and C. Vospe - in Spain has not been as well described. For the most time in Spain F. Gincburga worked in a hospital in Albacete, under the $35^{\text {th }}$ Division and at the end in hospital in Mataro. ${ }^{66}$ As far as known, for a while C. Vospe was a nurse at the Albacete, Benicasim and Mataro hospitals. ${ }^{67}$ Among Latvian women in Spain during the conflict was also M. Strazde. She worked as a typist in medical services. ${ }^{68}$

\section{Departure from Spain}

The majority of Latvian volunteers in medical aid left Spain in February 1939 together with Spanish refugees. However, as L. Kroms was a British citizen, he could leave Spain already in September 1938 after the withdrawal of volunteers. ${ }^{69}$ Around the same time, F. Gincburga left for Belgium. Her life ended tragically in Ravensbrück concentration camp in $1942 .{ }^{70}$ Having left slightly earlier than others, in the middle of January 1939 M. Strazde was already in France. Later than the majority, in 27 March 1939 L. Gutkins had the opportunity to embark on a ship in Alicante and leave for Africa, where he was placed in internment camps and prisons until released in 1943 after interference by a representative from the Soviet Union. ${ }^{71}$

J. Bahrahs (Kuba), Ž. Artmanis (R. Tellers), P. Bernštams, S. Levinsons and V. Kupcis after crossing Spanish-French border were placed in French internment 
camps. ${ }^{72} \bar{A}$. Šalits, after arriving in France, went to Paris. On 15 February 1939 he wrote a letter to Latvian legation in Paris and was one of the few Latvians that could return to Latvia before its occupation on 17 June $1940 .{ }^{73}$ The majority of Latvian men in internment camps were communists, yet V. Kupcis in Gurs internment camp managed to be split from the group of Latvian communists. However, even this separation did not help him to gain an advantage in the eyes of Latvian authorities and, like many others, he could not obtain legal documents to return to Latvia. V. Kupcis lived abroad for the rest of his life. $^{74}$ J. Bahrahs (Kuba) and C. Vospe also decided against returning to Latvia both of them could not receive documents from Latvian authorities. The father of J. Bahrahs (Kuba) even hired a lawyer to prove that there were no legal obstacles for his return. Already in Latvia since 5 April 1939, A. Šalits testified in favour of J. Bahrahs (Kuba), nonetheless, Latvian authorities delayed the decision to provide the citizen with necessary documents. ${ }^{75}$ Ž. Artmanis (R. Tellers) returned to the Soviet Union in $1939 .{ }^{76}$

P. Bernštams was released from internment camps upon the request of a Soviet representative and arrived in Moscow in March 1941, but S. Levinsons received the opportunity to go to the Soviet Union only in $1943 .{ }^{77}$ S. Švalbe was also placed in internment camps but, according to her memoirs, the conditions there were much better than those experienced by Latvian men in camps in Argelès, SaintCyprien and Gurs. She arrived in Moscow in $1941 .{ }^{78}$ An opportunity to return home or leave France was given to R. Volšonoka (Era), who arrived in Riga already in November 1939, and both Rudin sisters. M. Rudina was back in Latvia in 1939, while B. Rudina arrived in Moscow in the same year. ${ }^{79}$

\section{Conclusions}

Latvian volunteers in medical aid to the Spanish Republic differ from the average Latvian participants in the Spanish Civil War. First of all, out of 15 volunteers seven were female, who were the only Latvian women helping the Republicans in Spain. These women were not only nurses, - three of them were doctors. M. Rudina and B. Rudina (Voss) were even appointed to head hospitals. Another difference in this group in comparison with the Latvians fighting in the trenches was the high percentage of people with higher education, which is logical due to their profession. Several of these doctors spoke many foreign languages and had completed their studies abroad. That created difficulties in getting a job in Latvia, as they needed to study and receive a diploma from the University of Latvia. All volunteers in medical aid were born between 1897 and 1909, thus, at the time of reaching Spain they were around 30 to 40 years old. Most of them had a previous experience in different aspects of medical assistance.

As to motivation for participating in the Spanish Civil War, several of the volunteers were communists and considered it as their obligation to aid the Spanish Republic. The percentage of Jewish volunteers - 12 out of 15 - was much higher than on the average amongst the entire number of Latvian volunteers, which exceeded a hundred. Many well-educated doctors, who had seen life in Europe, might have chosen to leave their careers in order to fight against anti-Semitic views spread by Nazism and Fascism. Two volunteers claimed that they were recruited abroad, although some documents conflict these statements. The motivation was sufficiently high for eight volunteers to violate national law prohibiting to aid Republicans or Insurgents. 
In Spain, Latvian volunteers worked both near the front lines and in rear hospitals, they saved lives and cared for general health of soldiers and civilians. Some of them attained high positions and were promoted due to good quality of their work. However, political intrigues and suspicions were part of the atmosphere in the International Brigades, therefore even successful doctors - L. Kroms (Crome) and J. Bahrahs (Kuba) - were accused of misdeeds.
For many, leaving Spain was another life-changing experience, as not all of them could immediately return home. Some decided to stay abroad and were later deleted from the heroic stories of Latvians in the Spanish Civil War that were printed during Latvian SSR. The exception was F. Ginsburga, who died in Ravensbrück concentration camp. Others were welcomed by the Soviet Union during the Second World War.

\section{REFERENCES AND NOTES}

${ }^{1}$ The article was prepared within the framework of the project VPP-IZM-2018/1-0018 "Interaction between the individual, the society and the state in process of the history of Latvia: Conflicting values and formation of shared values during historical turning points".

${ }^{2}$ INESIS FELDMANIS. Ievads. In: IlgVARS Butulis, INESIS FELDMANIS, ĒRIKS JËKABSONS, INETA LipŠA, Aivars StrangA, JĀNIS TAurĒns, ANTONIJS ZundA. 15. maija Latvija. Riga 2017, p. 9.

${ }^{3}$ Ibidem; AIVARS STRANGA. K. Ulmaņa autoritārais režīms (1934-1940): politika, ideologiija, saimniecība. In: JĀNIS STRADIN̦Š (main ed.). Latvieši un Latvija: akadēmiskie raksti. Valstiskums Latvijā un Latvijas valsts - izcīnītā un zaudētā. Vol. II. Rīga 2013, p. 354; ILGVARS BUTULIS. Daži 1934. gada 15. maija apvērsuma aspekti K. Ulmaņa autoritārajā ideoloǵijā. In: VALTERS ŠČERBINSKIS, ËRIKS JĒKABSONS (comp.). Apvērsums: 1934. gada 15. maija notikumi avotos un pētījumos. Rìga 2012, p. 91.

${ }^{4}$ Political Department of the Ministry of Foreign Affairs. List of Non-intervention legal acts [Latvian]. Latvijas Nacionālais arhīvs, Latvijas Valsts vēstures arhīvs, Rīga (hereafter - LNA LVVA), 2574-4-7524, pp. 3-4.

${ }^{5}$ Report written by Kārlis Zariņš, Latvian Envoy Extraordinary and Minister Plenipotentiary in London, to Pauls Reinhards, Head of Western Division, Ministry of Foreign Affairs [Latvian], 30.09.1936. LNA LVVA, 2574-4-6534, p. 316; Report written by K. Zariňš to P. Reinhards [Latvian], 09.01.1937. Ibidem, 2574-4-6886, p. 201.

${ }^{6}$ HARIJS TRANZĒJs. 9 mēneši Spānijas pilsoṇu karā. Rīga 1938.

${ }^{7}$ SiguRdS Ziemelis (ed.). Latvijas cīnītāji Spānijā: 1936-1939. Atmiņas un dokumenti. Rīga 1966, pp. 126-127, 132-133, 195-196, 524, 526.

${ }^{8}$ For example, Artūrs Sprogís, Jānis Bērziņš, Pēteris Pumpurs, etc.

${ }^{9}$ Paul Preston. Dos médicos y una causa: Len Crome y Reginald Saxton en las Brigadas Internacionales. In: Ayer 2004, No. 56, pp. 37-66, here p. 37.

${ }^{10}$ ZIEMELIS, Latvijas cīnītāji Spānijā.

${ }^{11}$ Minutes of the party history sector meeting [Latvian], 07.06.1965. Latvijas Nacionālais arhīvs, Latvijas Valsts arhīvs, Rīga (hereafter - LNA LVA), PA-200-7-38, pp. 15-18.

${ }^{12}$ IGNACIO DE LA TORRE. Latvian Volunteers in the Spanish Civil War. In: Humanities and Social Sciences Latvia 24, 2016, No. 1, pp. 51-77.

${ }^{13}$ Preston, Dos médicos y una causa; Ovidil GoRChakov. Ian Berzin - komandarm GRU. St. Petersburg 2004; KONSTANTIN SEMENOV. Russkaja jemigracija i grazhdanskaja vojna v Ispanii 1936-1939 g. Moscow 2016; Los rusos en la guerra de España, 1936-1939. Madrid 2009; JĀNIS RIEKSTIN̦Š. Pulkvedis Hulio: dokumentāls apraksts par Padomju Savienības Varoni aviācijas 
generālleitnantu Pēteri Pumpuru un viṇa cīnu biedriem. Rīga 1988; EvgeniJ Vorob'Ev. Ja ne bojus' ne byt': dokumental'naja povest' o Geroe Sovetskogo Sojuza Pole Armane. Moskva 1982.

${ }^{14}$ Preston, Dos médicos y una causa, p. 37.

${ }^{15}$ RŪDOLFS LĀCIS (comp.). Viva república! Rīga 1957; ZIEMELIS, Latvijas cīnītāji Spānijā.

${ }^{16}$ Form completed by Jēkabs Bahrahs [Latvian], 05.06.1939. LNA LVVA, 2575-6-1709, p. 13.

${ }^{17}$ Ibidem; Affirmation written by Izaks Gocs [Latvian], 15.07.1939. Ibidem, 3234-24-591, p. 8.

${ }^{18}$ ARNIS VĪKSNA. Latvijas Universitātes Medicīnas fakultāte, 1919-1950. Rīga 2011, p. 476.

${ }^{19}$ Affirmation written by I. Gocs, 15.07.1939. LNA LVVA, 3234-24-591, p. 8.

${ }^{20}$ Appeal written by Voldemārs Kupcis to Latvian legation in Paris [Latvian]. Ibidem, 2575-6-1733, p. 26; Appeal written by V. Kupcis to the Emigration and Tourism Division of the Ministry of the Interior [Latvian], 12.1936. Ibidem, 3234-24-7659, p. 26.

${ }^{21}$ Appeal written by V. Kupcis. Ibidem, 3234-24-7659, p. 26.

${ }^{22}$ Statistics on Latvians participating in the Spanish Civil War gathered by Latvian historian Jānis Mende [Latvian]. LNA LVA, PA-53-1-66, pp. 4-16; SEMJONS LEVINSONS. Daugavpilieši Spānijā, manuscript [Latvian], 1965. Ibidem, PA-200-6-76, pp. 93-96.

${ }^{23}$ Form completed by Civja Vospe [Latvian], 08.05.1939. LNA LVVA, 2575-6-1758, p. 12.

${ }^{24}$ Ibidem; Form completed by J. Bahrahs [Latvian], 05.06.1939. Ibidem, p. 13.

${ }^{25}$ Letter written by C. Vospe to J. Bahrahs [Russian], 27.02.1939. Rossijskij gosudarstvennyj arhiv social'no-politicheskoj istorii, St. Petersburg (hereafter - RGASPI), 545-4-27, pp. 34-35; Letter written by C. Vospe to J. Bahrahs [Russian]. Ibidem, pp. 40-41.

${ }^{26}$ Preston, Dos médicos y una causa, pp. 39-41; Valdības iestāžu paziņojumi. In: Valdības Vēstnesis, 14.09.1934, p. 1.

${ }^{27}$ Statistics on Latvians participating in the Spanish Civil War gathered by J. Mende. LNA LVA, PA-53-1-66, pp. 4-16; Short biographical data about Latvian volunteers in Spain [Russian]. LNA LVA, PA-53-1-69, p. 10.

${ }^{28}$ ZIEMELIS, Latvijas cīnītāji Spānijā, p. 555.

${ }^{29}$ Statistics on Latvians participating in the Spanish Civil War gathered by J. Mende. LNA LVA, PA-53-1-66, pp. 4-16; SĀRA ŠVALBE. Frontes ārste Spānijā, manuscript [Latvian], 1965. Ibidem, PA-200-6-76, pp. 77-83.

${ }^{30}$ Ibidem.

${ }^{31}$ Riva LeIBOviČA. Dzīvības vārdā. In: LĀCIS, Viva república!, pp. 215-250, here pp. 218-223.

${ }^{32}$ Ibidem, p. 217; Statistics on Latvians participating in the Spanish Civil War gathered by J. Mende. LNA LVA, PA-53-1-66, pp. 4-16.

${ }^{33}$ ZIEMELIS, Latvijas cīnītāji Spānijā, p. 527.

${ }^{34}$ Protocol signed by Milda Šalits [Latvian], 04.03.1939. LNA LVVA, 3234-24-15153, p. 20.

${ }^{35}$ Appeal written by Ābrams Šalits to Latvian legation in Paris [Latvian], 15.02.1939. Ibidem, 25756-1750, p. 5.

${ }^{36}$ PeISAHS BERNŠTAMS. Medicīniskajā dienestā, manuscript [Latvian], 1965. LNA LVA, PA-2006-76, pp. 84-92; EVA VATERE. Ebreji - mediki Latvijā (1918-1996): enciklopēdija. Rīga 1997, p. 32; Appeal written by P. Bernštams to the Emigration and Tourism Division of the Ministry of the Interior [Latvian], 10.04.1937. LNA LVVA, 3234-24-1136, p. 1.

${ }^{37}$ Appeal written by Leiviks Gutkins to the Emigration and Tourism Division of the Ministry of the Interior [Latvian], 02.12.1936. LNA LVVA, 3234-24-4805, p. 23; LEIVIKS GUTKINS. Brīvības ienaidnieku rokās, manuscript [Latvian], 1966. LNA LVA, PA-200-6-76, pp. 97-103.

${ }^{38}$ Short biographical notes about Marina Strasde [Spanish]. RGASPI, 545-3-669L, pp. 149, 177; Statistics on Latvians participating in the Spanish Civil War gathered by J. Mende. LNA LVA, PA53-1-66, pp. 4-16. 
${ }^{39}$ Short biographical data about Rudin sisters [Latvian]. LNA LVA, PA-200-6-77, p. 229; Statistics on Latvians participating in the Spanish Civil War gathered by J. Mende. Ibidem, PA-53-1-66, pp. 4-16; Characteristics of Braina Voss [Spanish]. RGASPI, 545-3-669L, p. 84.

40 Preston, Dos médicos y una causa, p. 41.

${ }^{41}$ Ibidem, pp. 37-66.

${ }^{42}$ Short biographical data about Braina Rudina [Russian]. LNA LVA, PA-53-1-69, p. 37; ESTHER Bussot LiÑON. Les brigades internacionals L'hospital Militar Clínica núm. 4 de S'Agaró. Biografia de vuit brigadistes internacionals que hi moriren. Commemoració del 80è aniversari (1938-2018). In: Estudis del Baix Empordà 2018, Vol. 37, pp. 165-207.

${ }^{43}$ Characteristics of Braina Voss [Spanish]. RGASPI, 545-3-669L, p. 84; List of the Units of Foreign Medical Aid [Spanish]. Ibidem, 545-3-662, pp. 132-133; Position and characteristics of hospitals [Spanish]. Ibidem, pp. 149-150.

${ }^{44}$ LIÑON, Les brigades internacionals, p. 180.

${ }^{45}$ Ibidem, p. 170; Carlos. Report on political and cultural activities in hospitals during the last two weeks of August [Spanish], 31.08.1938. RGASPI, 545-3-662, pp. 49-52.

${ }^{46}$ Autobiography written by Mirjama Rudina [Russian], at the end of 1970s. Latvijas Kara Muzejs, Inv. No. 3-71081/1674-VII; FRANCISCO FUSTER RUIZ. El servicio de sanidad de las Brigadas Internacionales. Albacete 2018, pp. 164-165.

${ }^{47}$ Characteristics of Mirjama Rudina [Spanish]. RGASPI, 545-3-669L, p. 83.

${ }^{48}$ Ibidem; B. Rudina's (Voss) opinion about brochure prepared by Gusti Jirku [French], 08.12.1939. Ibidem, 545-2-453, p. 60.

${ }^{49}$ Autobiography written by V. Kupcis [Russian]. Ibidem, 545-6-606, pp. 19-23; Appeal written by V. Kupcis. Ibidem, p. 26; Form completed by V. Kupcis [Latvian], 19.08.1939. LNA LVVA, 25756-1733, p. 22.

${ }^{50}$ Augusts Ratnieks. Sapieru dienestā Spānijā, manuscript [Latvian]. Personal archive of Rita Ruduša.

${ }^{51}$ RuIZ, El servicio de sanidad, pp. 109, 183; Affirmation written by Ābrams Šalits [Latvian], 12.07.1939. LNA LVVA, 3234-24-591, p. 9.

${ }^{52}$ Description of medical services in the International Brigades [Spanish]. RGASPI, 545-3-701, p. 28.

${ }^{53}$ RŪDOLFS LĀCIS. Divi gadi Spānijā. In: LĀCIS, Viva república!, p. 87.

${ }^{54}$ RuIZ, El servicio de sanidad, p. 110; Short biographical data about Latvian volunteers in Spain [Russian]. LNA LVA, PA-53-1-69, pp. 10-11.

${ }^{55}$ ZIEMELIS, Latvijas cīnītāji Spānijā, p. 90; Short characteristics of volunteers [Spanish]. RGASPI, 545-3-669, p. 177.

${ }^{56}$ S. ŠVALBE. Frontes ārste Spānijā, manuscript [Latvian], 1965. LNA LVA, PA-200-6-76, pp. 77-83.

${ }^{57}$ P. BERNŠTAMS. Medicīniskajā dienestā, manuscript [Latvian], 1965. Ibidem, pp. 84-92.

${ }^{58}$ Ibidem.

${ }^{59}$ L. GUTKINS. Brīvības ienaidnieku rokās, manuscript [Latvian], 1966. Ibidem, pp. 97-103.

${ }^{60}$ S. LEVINSONS. Daugavpilieši Spānijā, manuscript [Latvian], 1965. Ibidem, pp. 93-96.

${ }^{61}$ Appeal written by Ābrams Šalits to Latvian legation in Paris [Latvian], 15.02.1939. LNA LVVA, 2575-6-1750, p. 5; Affirmation written by Ābrams Šalits [Latvian], 12.07.1939. Ibidem, p. 9.

${ }^{62}$ Characteristics of Dr. Ābrams Šalits [Spanish]. RGASPI, 545-3-669L, p. 86.

${ }^{63}$ LEIBOviČA, Dzīvības vārdā, pp. 225-236; GUSTI JiRKU. La lettone Era raconte [French]. RGASPI, 545-2-188, pp. 244-246.

${ }^{64}$ JĀNIS ĀBOLS. Vēstule no Spānijas. In: Strādnieku Cīṇa, 25.06.1938, p. 1.

${ }^{65}$ GUSTI JiRKU. Era, eine Lettin, erzaehlt [German]. RGASPI, 545-2-453, p. 62. 
${ }^{66}$ Characteristics of Mara Frida Ginsberg [Spanish]. RGASPI, 545-3-669L, p. 98.

${ }^{67}$ Information on Civja Vospe [Spanish]. Ibidem, 545-3-701, p. 95; Information on Civja Vospe collected by J. Mende [Latvian and Russian]. LNA LVA, PA-53-1-74, pp. 151-153; Short information on C. Vospe [Spanish]. RGASPI, 545-3-670, p. 27.

${ }^{68}$ Short biographical notes about Marina Strasde [Spanish]. RGASPI, 545-3-669L, p. 149.

${ }^{69}$ Preston, Dos médicos y una causa, p. 48.

${ }^{70}$ Short biographical data about Frida Gincburg [Russian]. LNA LVA, PA-53-1-69, p. 105.

${ }^{71}$ L. GUTKINS. Brīvības ienaidnieku rokās, manuscript [Latvian], 1966. Ibidem, pp. 97-103.

${ }^{72}$ GINTA IEVA BIKŠE. Latvijas brīvprātīgie Spānijas pilsoṇu karā (1936.-1939. g.): personu lietu dokumenti Latvijas Valsts vēstures arhīva Latvijas diplomātisko un konsulāro pārstāvniecību ārzemēs fondā. In: Dokumentārā mantojuma bagātības Latvijas arhīvos. Rīga 2020, pp. 149-171; Short biographical data about Žanis Artmanis [Russian]. LNA LVA, PA-53-1-69, pp. 10-11.

${ }^{73}$ BIKŠE, Latvijas brīvprātīgie Spānijas pilsoṇu karā, pp. 149-171.

${ }^{74}$ Ibidem.

${ }^{75}$ Ibidem; Description of J. Bahrahs case [Latvian], 19.08.1939. LNA LVVA, 3234-24-591, pp. 1-3.

${ }^{76}$ Short biographical data about Žanis Artmanis [Russian]. LNA LVA, PA-53-1-69, pp. 10-11.

${ }_{77}$ Short biographical data about Peisahs Bernštams and S. Levinsons [Russian]. Ibidem, pp. 59-60, 71.

${ }^{78}$ Short biographical data about Sāra Švalbe [Russian]. Ibidem, p. 132.

${ }^{79}$ Short biographical data about M. and B. Rudinas [Russian]. Ibidem, pp. 120-121.

\section{KOPSAVILKUMS}

Raksts sniedz pārskatu par 15 brīvprātīgajiem no Latvijas, kuri piedalījās medicīniskās palīdzības sniegšanā republikāṇu kontrolētajās teritorijās Spānijā. Kopumā ar Latviju saistītie brīvprātīgie pārsvarā bija vīrieši, taču šajā personu grupā bija ievērojams skaits sieviešu, turklāt ne tikai medmāsas (R. Volšonoka (Era), F. Gincburga, C. Vospe) un mašīnrakstītāja (M. Strazde), bet arī ārstes (B. Rudina (Vosa), M. Rudina un S. Švalbe). Dažiem brīvprātīgajiem Spānijā atradās arī citi ğimenes locekḷi, piemēram, republikāṇus atbalstīja māsu Rudinu brālis un B. Rudinas (Vosas) vīrs. Ciešākas attiecības saistīja arī J. Bahrahu un C. Vospi. Lielākā daḷa brīvprātīgo medicīniskajā dienestā bija iestājušies komunistiskajās partijās vai ar tām saistītās organizācijās. Tomēr bija arī bezpartejiski brīvprātīgie, piemēram, V. Kupcis, Ā. Šalits, M. Strazde, bet L. Kroms (Crome) iestājās komunistiskajā partijā pēc Spānijas atstāšanas. Medicīniskā personāla vidū procentuāli Latvijas ebreju bija ievērojami vairāk nekā kopumā visu ar Latviju saistāmo brīvprātīgo vidū. Liela daḷa ārstu bija studējuši ārzemēs un saṇēmuši ārvalstu diplomu, kas neḷāva iegūt darbu Latvijā bez studijām Latvijas Universitātē. Dzimuši starp 1897. un 1909. gadu, medicīniskā dienesta darbinieki Spānijā ieradās, būdami 30-40 gadu vecumā, turklāt lielākoties jau ar pieredzi un zināšanām, kas nepieciešamas medicīniskās palīdzības sniegšanai.

Uz Spāniju brīvprātīgie no Latvijas devās jau no 1936. gada: visagrāk J. Bahrahs (Kuba), bet visvēlāk B. Rudina (Vosa) - 1938. gadā. Lielākā daḷa Spānijā ieradās 1937. gadā, un daudzus brīvprātīgos neatturēja arī Latvijas oficiālais aizliegums 1937. gada 23. februārī doties uz Spāniju, lai palīdzētu kādai no karojošajām pusēm. Augstākus amatus Spānijā ieņēma L. Kroms (Crome), B. Rudina (Vosa), M. Rudina, V. Kupcis, J. Bahrahs (Kuba) un Ž. Artmanis (R. Tellers). Piemēram, L. Kroms (Crome) kḷuva par 35. divīzijas sanitārās 
daḷas priekšnieku, V. Kupcis - par farmaceitisko dienestu priekšnieku V un XV korpusā, bet B. Vosa - par slimnīcas Sagaro vadītāju. Vairāki brīvprātīgie Spānijā bija iesaistīti politiskās aktivitātēs, piemēram, R. Volšonoka (Era), P. Bernštams, bet citi - L. Kroms (Crome) un J. Bahrahs (Kuba) - ierauti komunistu intrigās.

Visi ar Latviju saistītie brīvprātīgie Spāniju atstāja 1938. gadā pēc ārvalstu brīvprātīgo atsaukšanas no frontes vai 1939. gadā, frankistiem ieņemot Katalonijas teritoriju un republikāņiem zaudējot karā. 1939. gada februārī, šḳērsojot Spānijas un Francijas robežu, daḷa vīriešu un S. Švalbe nonāca internēto nometnēs. Dažiem brīvprātīgajiem, it īpaši sievietēm, izdevās atgriezties Latvijā pirms Latvijas okupācijas, tomēr daḷa palika ārzemēs vai piedzīvoja salīdzinoši sarežgítu ceḷu mājup un Latvijā varēja atgriezties vien pēc Padomju Savienības diplomātisko pārstāvju iejaukšanās Otrā pasaules kara laikā. L,oti tragiski beidzās medmāsas F. Gincburgas dzīve, viṇa nokḷuva Rāvensbrukas koncentrācijas nometnē, kur arī nomira. 